\title{
Detection of Vibrio cholerae and Acanthamoeba species from same natural water samples collected from different cholera endemic areas in Sudan
}

Salah Shanan ${ }^{1,3}$, Hadi Abd², Ingela Hedenström², Amir Saeed ${ }^{1}$ and Gunnar Sandström ${ }^{\text {* }}$

\begin{abstract}
Background: Vibrio cholerae $\mathrm{O} 1$ and V. cholerae 0139 infect humans, causing the diarrheal and waterborne disease cholera, which is a worldwide health problem. $V$. cholerae and the free-living amoebae Acanthamoeba species are present in aquatic environments, including drinking water and it has shown that Acanthamoebae support bacterial growth and survival. Recently it has shown that Acanthamoeba species enhanced growth and survival of V. cholerae $\mathrm{O} 1$ and 0139 . Water samples from different cholera endemic areas in Sudan were collected with the aim to detect both $V$. cholerae and Acanthamoeba species from same natural water samples by polymerase chain reaction $(P C R)$.
\end{abstract}

Findings: For the first time both $V$. cholerae and Acanthamoeba species were detected in same natural water samples collected from different cholera endemic areas in Sudan. 89\% of detected V. cholerae was found with Acanthamoeba in same water samples.

Conclusions: The current findings disclose Acanthamoedae as a biological factor enhancing survival of $V$. cholerae in nature.

\section{Background}

Vibrio cholerae species are widely distributed in aquatic environments [1]. They comprise nearly 200 serogroups based on the $\mathrm{O}$ antigenic structures [2]. V. cholerae $\mathrm{O} 1$ and $V$. cholerae $\mathrm{O} 139$ infect humans, causing the diarrheal and waterborne disease cholera [3], which is a worldwide health problem.

$V$. cholerae inhabits aquatic environments and human intestines [4], and cholera outbreaks are associated with contaminated food and water supplies. The seasonality of cholera has been associated with physical and biological factors [5]; however, many factors affect the survival of $V$. cholerae in aquatic environments such as attachment to plankton, loss to predators [6].

\footnotetext{
* Correspondence: gunnar.sandstrom@ki.se

${ }^{1}$ Karolinska Institute, Department of Laboratory Medicine, Division of Clinical Microbiology, Karolinska University Hospital, Huddinge, SE-141 86 Stockholm, Sweden

Full list of author information is available at the end of the article
}

Acanthamoebae are free-living protozoa distributed worldwide in nature $[7,8]$ and may affect the survival of $V$. cholerae. It is well known that $V$. cholerae and Acanthamoeba species are present in aquatic environments, including drinking water [9-11] and the use of water with poor microbiological quality increases the risk of human illness since acanthamoebae and bacteria are involved in complex interactions important to medical and environmental microbiology. It is known that acanthamoebae benefit from extracellular bacteria as food, which may enhance survival of the amoebae in different environments. In contrast, the role of Acanthamoebae as hosts for bacteria has been proposed for many pathogenic bacteria [12-24].

Recent publications [25-28] showed that Acanthamoeba species enhanced growth and survival of $V$. cholerae $\mathrm{O} 1$ and $\mathrm{O} 139$ in laboratory microcosm co-culture experiments, but no study has so far been published on the detection of both $V$. cholerae and Acanthamoeba from similar sites. In this context, cholera is endemic and poses
C Biomed Central

(c) 2011 Sandström et al; licensee BioMed Central Ltd. This is an Open Access article distributed under the terms of the Creative Commons Attribution License (http://creativecommons.org/licenses/by/2.0), which permits unrestricted use, distribution, and reproduction in any medium, provided the original work is properly cited. 
a persistent threat to the public health in Sudan. It has been shown that cholera outbreaks, which occurred between April and August 2006 caused 6254 cases including 204 deaths with a case fatality rate of $3.2 \%$ in Northern Sudan [29].

In this paper, water samples from different cholera endemic areas in Sudan were collected with the aim to detect both $V$. cholerae and Acanthamoeba species from similar sites of collected natural water samples by polymerase chain reaction (PCR).

\section{Materials and methods Sample collection}

Four hundred water samples collected from 4 states in Sudan previously known as foci of $V$. cholerae. The states are Gadarif, Juba, Kordofan and Khartoum. 128 samples were from zeers (home pots), 167 from hafirs (a hafir is an underground reservoir designed for storing rain water carried by streams and used for domestic water supply and for agricultural purposes in rural areas in the Sudan), and 66 from water tanks and 39 from lakes.

\section{DNA extraction}

$50 \mathrm{ml}$ water was centrifuged for $10 \mathrm{~min}$ at $4000 \mathrm{rpm}$ and the pellets were used for DNA extraction using Qiagen DNA mini kit (Qiagen, Valencia, CA, USA).

\section{DNA amplification}

In the first reaction two primers sets were used. One set, referred to as the AcU primer 5'- GGC CCA GAT CGT TTA CCG TGA A-3' and the Ac L primer 5'-TCT CAC AAG CTG CTA GGG GAG TCA-3' and in the second reaction also two primers sets were used, one set referred to as the VCT-1 primer 5'-ACA GAG TGA GTA CTT TGA CC-3' and the VCT-2 primer 5' ATA CCA TCC ATA TAT TTG GGA G-3' PCR were carried out for the both reactions in a final volume of $20 \mu \mathrm{l}$ containing each primer at a concentration of $0.3 \mu \mathrm{M}$, $1.0 \times$ PCR golden buffer, $200 \mu \mathrm{M}$ deoxyribonucleoside triphospate, $1.2 \mathrm{mM} \mathrm{Mgcl}_{2}, 1.25 \mathrm{U} / 50 \mu \mathrm{l}$ of Ampli Taq Gold (Sigma).

\section{Gel analysis of PCR product}

PCR condition were: 32 cycles of $95^{\circ} \mathrm{C}$ (denaturation) for $4 \mathrm{~min}, 55^{\circ} \mathrm{C}$ (annealing) for $20 \mathrm{sec}$, and $72^{\circ} \mathrm{C}$ for 10 sec (extension). PCR products were analyzed by electrophoresis on agarose gel in $1 \times$ TBE buffer (Tri base, boric acid and EDTA ( $\mathrm{pH}$ 8.0). The gel was stained in $0.1 \%$ SYBR Green bath, visualized by UV translumination, and photographed using Polaroid films. DNA fragment 487 bp for Acanthamoeba was obtained in the first reaction and DNA fragment 308 bp for Vibrio cholerae toxin was obtained in the second reaction.

\section{Statistical analysis}

$\chi 2$ test was performed for comparative statistical analysis of together-and alone-detected microorganisms to show the significant existence of alone $V$. cholerae or that found with Acanthamoeba.

\section{Results and discussion}

$V$. cholerae $\mathrm{O} 1$ and $V$. cholerae $\mathrm{O} 139$ are widely distributed in aquatic environments [17] causing the diarrheal and waterborne disease cholera [22]. V. cholerae and Acanthamoeba species are present in aquatic environments, including drinking water $[9,16,19]$. A number of studies report that free-living amoebae (FLA) support survival of pathogenic bacteria [19] and more studies are still needed on distribution of $V$. cholerae and FLA in nature [30]. In the current study we collected water samples from endemic areas in Sudan to detect $V$. cholerae and Acanthamoeba species in same natural water samples by PCR targeting cholera toxin gene (toxA) and Acanthamoeba $18 \mathrm{~S}$ RNA gene.

A total of 400 water samples were examined by PCR to detect $V$. cholerae toxin gene (toxA) and Acanthamoeba 18 S RNA gene. The result showed that 8 water samples numbered $8,117,121,150,156,160,193$, and 213 contained both $V$. cholerae and Acanthamoeba (table 1). Furthermore, it was found that only one water sample contained $V$. cholerae (number 54) compared to 13 samples numbered 24, 46, 70, 84, 87, 128, 177, 202, 259, 266, 287, 319, and 397, which contained Acanthamoeba only (table 1).

Analyzing presence of detected microorganisms showed that the detected number of together- and alone-identified microorganisms (amoebae and bacteria) (table 2) was significantly differed ( $p$ value of $\chi 2$ was $<0.05$ ). $V$. cholerae needs to be found with other microorganisms such as Acanthamoebae a finding disclosed by this study since $89 \%$ of detected $V$. cholerae was found with Acanthamoebae compared to $11 \% \mathrm{~V}$. cholerae, which was found alone. As regards amoebae $38 \%$ of Acanthamoebae was found with $V$. cholerae and $62 \%$ was found alone. Moreover, prevalence of $V$. cholerae alone was $0.25 \%$ and that of Acanthamoeba alone was $3.25 \%$, while prevalence of both Acanthamoeba and V. cholerae was 2\% (table 2). Taken together, this clearly shows that Acanthamoeba and $V$. cholerae can be isolated at similar sites but it does not disclose interaction between them. However, in previous studies it has been found that Acanthamoeba and V. cholerae interact in beneficial ways for both microorganisms and it could thus be speculated that such interaction is important for the microorganisms also in nature. [12-24].

For the first time this study show that both $V$. cholerae and Acanthamoeba species can be detected in the same natural water samples collected from different cholera endemic areas in Sudan. 89\% of detected V. cholerae was 
Table 1 PCR result showing positive Acanthamoeba and V. cholerae in same sample and Acanthamoeba or $\mathbf{V}$. cholerae alone

\begin{tabular}{|c|c|c|c|c|}
\hline Sample number & Region & Source & V. cholerae & Acanthamoebae \\
\hline 8 & Gadarif & zeer & $+v e$ & $+v e$ \\
\hline 24 & Gadarif & zeer & -ve & + ve \\
\hline 46 & Gadarif & hafir & -ve & + ve \\
\hline 54 & Gadarif & hafir & + ve & -ve \\
\hline 70 & Gadarif & hafir & -ve & + ve \\
\hline 84 & Gadarif & $\operatorname{tank}$ & -ve & + ve \\
\hline 87 & Gadarif & tank & -ve & + ve \\
\hline 117 & Gadarif & tank & + ve & + ve \\
\hline 121 & Gadarif & tank & + ve & + ve \\
\hline 128 & Gadarif & $\operatorname{tank}$ & -ve & + ve \\
\hline 150 & Juba & lake & + ve & + ve \\
\hline 156 & Juba & lake & + ve & + ve \\
\hline 160 & Juba & lake & + ve & + ve \\
\hline 177 & Juba & zeer & + ve & + ve \\
\hline 193 & Juba & zeer & + ve & +ve \\
\hline 202 & Juba & zeer & -ve & +ve \\
\hline 213 & Khartoum & lake & + ve & + ve \\
\hline 259 & Khartoum & zeer & -ve & + ve \\
\hline 266 & Khartoum & zeer & -ve & + ve \\
\hline 287 & Kordofan & hafir & -ve & + ve \\
\hline 319 & Kordofan & hafir & -ve & + ve \\
\hline 397 & Kordofan & hafir & -ve & + ve \\
\hline
\end{tabular}

found with Acanthamoeba and 11\% was found alone. Taken together role of Acanthamoeba species in survival of $V$. cholerae $[18,25,26,31]$ may strongly disclose Acanthamoedae as a biological factor enhancing survival of $V$. cholerae in nature.

Acanthamoebae support bacterial survival and growth $[12,25,26,31]$ and save the bacteria from the effects of chlorination [5], antibodies [5] and antibiotics [12,25, $26,31]$, increasing the risk of human illness caused by bacteria or Acanthamoebae. Accordingly, a need to find an effective means of detection and killing of both Acanthamoeba and bacteria is warranted to reduce the risk of spread of $V$. cholerae.

\section{Conclusions}

$89 \%$ of detected $V$. cholerae was found with Acanthamoeba disclosing Acanthamoedae as a biological factor enhancing survival of $V$. cholerae in nature.

Table 2 Prevalence of detected microorganisms

\begin{tabular}{lcc}
\hline Detected microorganisms & Positive & Prevalence $\%$ \\
\hline Acanthamoeba and $V$. cholerae & $8 / 400$ & 2 \\
\hline Acanthamoeba only & $13 / 400$ & 3.25 \\
\hline V. cholerae only & $1 / 400$ & 0.25 \\
\hline
\end{tabular}

\section{Acknowledgements}

This project was supported by the Swedish Civil Contingencies Agency, project No. 800/2008 and Swedish Agency for Research Cooperation with Developing Countries, Project No. SWE-2006-044.

\section{Author details}

'Karolinska Institute, Department of Laboratory Medicine, Division of Clinical Microbiology, Karolinska University Hospital, Huddinge, SE-141 86 Stockholm, Sweden. ${ }^{2}$ Swedish Institute for Infectious Disease Control, SE-17182 Solna, Sweden. ${ }^{3}$ University of Medical Sciences and Technology, Faculty of Medical Laboratory Sciences, Khartoum, Sudan.

\section{Authors' contributions}

SS collected the samples extracted DNA and perform PCR and gel electrophoresis. HA conceived the study, draft the manuscript and performed the statistical analysis. IH guided PCR and gel electrophoresis. AS participated in writing. GS participated in writing and critical reading. All authors read and approved the final manuscript.

\section{Competing interests}

The authors declare that they have no competing interests.

Received: 10 January 2011 Accepted: 7 April 2011

Published: 7 April 2011

\section{References}

1. Faruque SM, Albert MJ, Mekalanos JJ: Epidemiology, genetics, and ecology of toxigenic Vibrio cholerae. Microbiol Mol Biol Rev 1998, 62(4):1301-1314

2. Yamai S, Okitsu T, Shimada T, Katsube Y: [Distribution of serogroups of Vibrio cholerae non-O1 non-0139 with specific reference to their ability to produce cholera toxin, and addition of novel serogroups]. Kansenshogaku Zasshi 1997, 71(10):1037-1045.

3. Reidl J, Klose KE: Vibrio cholerae and cholera: out of the water and into the host. FEMS Microbiol Rev 2002, 26(2):125-139.

4. Faruque SM, Naser IB, Islam MJ, Faruque AS, Ghosh AN, Nair GB, Sack DA, Mekalanos JJ: Seasonal epidemics of cholera inversely correlate with the prevalence of environmental cholera phages. Proc Natl Acad Sci USA 2005, 102(5):1702-1707.

5. Lipp EK, Huq A, Colwell RR: Effects of global climate on infectious disease: the cholera model. Clin Microbiol Rev 2002, 15(4):757-770.

6. Cottingham KL, Chiavelli DA, Taylor RK: Environmental microbe and human pathogen: the ecology and microbiology of Vibrio cholerae. Ecology and the Environment 2003, 1:80-86.

7. Brown TJ, Cursons RT, Keys EA: Amoebae from antarctic soil and water. Appl Environ Microbiol 1982, 44(2):491-493.

8. Martinez AJ, Visvesvara GS: Free-living, amphizoic and opportunistic amebas. Brain Pathol 1997, 7(1):583-598.

9. Backer $\mathrm{H}$ : Water disinfection for international and wilderness travelers. Clin Infect Dis 2002, 34(3):355-364.

10. Brown MR, Barker J: Unexplored reservoirs of pathogenic bacteria: protozoa and biofilms. Trends Microbiol 1999, 7(1):46-50

11. Greub G, Raoult D: Microorganisms resistant to free-living amoebae. Clin Microbiol Rev 2004, 17(2):413-433.

12. Abd H, Johansson T, Golovliov I, Sandstrom G, Forsman M: Survival and growth of Francisella tularensis in Acanthamoeba castellanii. Appl Environ Microbiol 2003, 69(1):600-606.

13. Alsam S, Jeong SR, Sissons J, Dudley R, Kim KS, Khan NA: Escherichia coli interactions with Acanthamoeba: a symbiosis with environmental and clinical implications. J Med Microbiol 2006, 55(Pt 6):689-694.

14. Axelsson-Olsson D, Waldenstrom J, Broman T, Olsen B, Holmberg M Protozoan Acanthamoeba polyphaga as a potential reservoir for Campylobacter jejuni. Appl Environ Microbiol 2005, 71(2):987-992.

15. Barker J, Humphrey TJ, Brown MW: Survival of Escherichia coli 0157 in a soil protozoan: implications for disease. FEMS Microbiol Lett 1999, 173(2):291-295.

16. Cirillo JD, Falkow S, Tompkins LS: Growth of Legionella pneumophila in Acanthamoeba castellanii enhances invasion. Infect Immun 1994, 62(8):3254-3261.

17. Gaze WH, Burroughs N, Gallagher MP, Wellington EM: Interactions between Salmonella typhimurium and Acanthamoeba polyphaga, and 
observation of a new mode of intracellular growth within contractile vacuoles. Microb Ecol 2003, 46(3):358-369.

18. Jeong HJ, Jang ES, Han Bl, Lee KH, Ock MS, Kong HH, Chung DI, Seol SY, Cho DT, Yu HS: Acanthamoeba: could it be an environmental host of Shigella? Exp Parasitol 2007, 115(2):181-186.

19. King $C H$, Shotts EB, Wooley RE, Porter KG: Survival of coliforms and bacterial pathogens within protozoa during chlorination. Appl Environ Microbiol 1988, 54(12):3023-3033.

20. La Scola B, Raoult D: Survival of Coxiella burnetii within free-living amoeba Acanthamoeba castellanii. Clin Microbiol Infect 2001, 7(2):75-79.

21. Ly TM, Muller HE: Ingested Listeria monocytogenes survive and multiply in protozoa. J Med Microbiol 1990, 33(1):51-54.

22. Saeed A, Abd H, Edvinsson B, Sandstrom G: Acanthamoeba castellanii an environmental host for Shigella dysenteriae and Shigella sonnei. Arch Microbiol 2009, 191(1):83-88.

23. Steinert M, Birkness K, White E, Fields B, Quinn F: Mycobacterium avium bacilli grow saprozoically in coculture with Acanthamoeba polyphaga and survive within cyst walls. Appl Environ Microbiol 1998, 64(6):2256-2261.

24. Winiecka-Krusnell J, Wreiber K, von Euler A, Engstrand L, Linder E: Freeliving amoebae promote growth and survival of Helicobacter pylori. Scand I Infect Dis 2002, 34(4):253-256.

25. Abd H, Saeed A, Weintraub A, Nair GB, Sandstrom G: Vibrio cholerae 01 strains are facultative intracellular bacteria, able to survive and multiply symbiotically inside the aquatic free-living amoeba Acanthamoeba castellanii. FEMS Microbiol Ecol 2007, 60(1):33-39.

26. Abd H, Saeed A, Weintraub A, Sandstrom G: Vibrio cholerae 0139 requires neither capsule nor LPS O side chain to grow inside Acanthamoeba castellanii. J Med Microbiol 2009, 58(Pt 1):125-131.

27. Saeed A, Abd H, Edvinsson B, Sandström G: Vibrio choleraeAcanthamoeba castellanii interaction showing endosymbiont-host relation. Symbiosis 2007, 44:153-158.

28. Sandstrom G, Saeed A, Abd H: Acanthamoeba polyphaga is a possible host for Vibrio cholerae in aquatic environments. Exp Parasitol 2010, 126(1):65-68,

29. Organization WH: Health Action in Crises. Highlights No 1222006.

30. Vezzulli L, Pruzzo C, Anwar Huq H, Colwell R: Environmental reservoirs of Vibrio cholerae and their role in cholera. Environmental Microbiology Reports 2010, 2:27-33.

31. Abd H, Weintraub A, Sandstrom G: Intracellular survival and replication of Vibrio cholerae 0139 in aquatic free-living amoebae. Environ Microbiol 2005, 7(7):1003-1008

doi:10.1186/1756-0500-4-109

Cite this article as: Shanan et al.: Detection of Vibrio cholerae and Acanthamoeba species from same natural water samples collected from different cholera endemic areas in Sudan. BMC Research Notes 2011 4:109.

\section{Submit your next manuscript to BioMed Central and take full advantage of:}

- Convenient online submission

- Thorough peer review

- No space constraints or color figure charges

- Immediate publication on acceptance

- Inclusion in PubMed, CAS, Scopus and Google Scholar

- Research which is freely available for redistribution 